\title{
WORKSOP PENYUSUNAN RANCANGAN PEMBELAJARAN MODEL MIND MAPPING UNTUK SD NEGERI 3 MIDANG
}

\author{
Itsna Oktaviyanti", Nurhasanah, Ilham Syahrul Jiwandono, \\ Baiq Niswatul Khair, Ratnadi, Lalu Hamdian Affandi \\ Program Studi Pendidikan Guru Sekolah Dasar FKIP Universitas Mataram
}

Kata Kunci: Mind Mapping, Rancangan Pembelajaran

\begin{abstract}
Abstrak: Peraturan Menteri tentang Standar Proses Pendidikan Dasar dan Menengah mengamantkan bahwa proses pembelajaran pada pendidikan dasar seharunya menyenangkan. Pembelajaran yang menyenangkan bisa didapatkan melalui penerapan model pembelajaran kooperatif salah satunya Mind Mapping. Mind Mapping merupakan model pembelajaran dengan cara meringkas materi dalam bentuk gambar mind map yang menarik dapat mempermudah siswa dalam memahami materi yang banyak. Namun, kebanyakan guru lebih memilih menggunakan metode konvensioanal seperti ceramah dalam menyampaikan materi, hal tersebut terjadi di SD Negeri 3 Midang. Alasan yang diberikan guru antara lain sulitnya manajemen waktu dalam persiapan menggunakan model pembelajaran dan ketidaktahuan ataupun tidak paham dengan model pembelajaran terkini yang dinilai efektif dan menyenangkan. Tujuan dalam kegiatan ini yaitu mengenalkan model Mind Mapping kepada guru SD N 3 Midang dan meningkatkan kesadaran guru untuk merencanakan pembelajaran dengan model pembelajaran yang inovatif agar pembelajaran lebih bermakna. Kegiatan pengabdian ini dilakukan dengan metode sosialisasi dan pelatihan. Sosialisasi dilakukan dengan menjelaskan segala hal mengenai model Mind Mapping seperti pengertian, manfaat, hingga kelebihan dan kekuranan Mind Mapping serta langkah-langkah pembelajarannya. Metode pelatihan dilaksanakan dengan cara berkelompok dalam pembuatan mind mapp. Kegiatan yang telah dilaksanakan dapat dikatakan berhasil, yang ditunjukkan dengan antusiasme yang tinggi dari para peserta dalam menyimak setiap materi, ditandai dengan banyaknya pertanyaan yang muncul dari para peserta. Selain itu saat proses pelatihan pembuatan mind map, peserta tampak bersemangat dengan terus menunjukkan perkembangan karyanya. Hal tersebut dapat digunakan sebagai indikator adanya perubahan pola pikir dan wawasan dari peserta untuk merencanakan pembelajaran menggunakan model Mind Mapping.
\end{abstract}

Korspodensi: email itsna@unram.ac.id

\section{PENDAHULUAN}

Standar Proses adalah kriteria mengenai pelaksanaan pembelajaran pada satuan pendidikan untuk mencapai Standar Kompetensi Lulusan. Dengan demikian setiap proses pembelajaran memiliki standar dalam mencapai standar kelulusan kompetensi yang diharapkan. Berdasarkan Peraturan Menteri No. 22 Tahun 2016 tentang Standar Proses Pendidikan Dasar dan Menengah, dijelaskan bahwa proses Pembelajaran pada satuan pendidikan diselenggarakan secara interaktif, inspiratif, menyenangkan, menantang, memotivasi peserta didik untuk berpartisipasi aktif, serta memberikan ruang yang cukup bagi prakarsa, kreativitas, dan kemandirian sesuai dengan bakat, minat, dan perkembangan fisik serta psikologis peserta didik. Untuk itu setiap satuan pendidikan melakukan perencanaan pembelajaran, pelaksanaan proses pembelajaran serta penilaian proses pembelajaran untuk meningkatkan efisiensi dan efektivitas ketercapaian kompetensi lulusan. 
Dalam perencanaan pembelajaran, guru melakukan proyeksi apa yang akan dilakukan oleh guru tersebut dalam proses belajar mengajar (Mustofa 2011: 6). Adapun proyeksi yang dilakukan guru diantaranya adalah proses penyusunan materi pelajaran, penggunaan media, pendekatan dan metode, serta penilaian pembelajaran dalam suatu alokasi waktu yang akan dilaksanakan pada masa tertentu untuk mencapai tujuan yang telah ditentukan (Majid 2012: 17). Salah satu hal terpenting dalam perencanaan pembelajaran adalah penyusunan pendekatan dan metode atau model pembelajaran yang akan digunakan.

Menurut Dahlan dalam Isjoni (2010: 49), model pembelajaran merupakan suatu rencana atau pola yang digunakan dalam menyusun kurikulum, mengatur materi pelajaran, dan memberi petunjuk kepada pengajar di kelas. Joyce \& Weil dalam Rusman (2011: 133) menambahkan, model pembelajaran adalah suatu rencana atau pola yang dapat digunakan untuk membentuk kurikulum (rencana pembelajaran jangka panjang), merancang bahanbahan pembelajaran, dan membimbing pembelajaran di kelas atau yang lain. Sementara Trianto (2011: 52) mengartikan model pembelajaran sebagai kerangka konseptual yang menggambarkan prosedur sistematik dalam mengorganisasikan pengalaman belajar untuk mencapai tujuan belajar dan berfungsi sebagai pedoman bagi perancang pembelajaran dan para guru dalam merancang dan melaksanakan pembelajaran.

Dari beberapa pendapat tentang pengertian model pembelajaran di atas, dapat disimpulkan bahwa model pembelajaran adalah suatu rancangan yang disusun sebagai pedoman dalam melaksanakan pembelajaran untuk mencapai tujuan belajar. Ada beberapa model pembelajaran salah satunya model pembelajaran kooperatif. Menurut Latipah dan Adman (2018: 130) model pembelajaran kooperatif lebih menekankan pada kerja sama dan hal ini akan meningkatkan keaktifan siswa sehingga mereka akan mudah untuk memahami konsep dengan menyenangkan. Model pembelajaran kooperatif diantaranya yaitu : Jigsaw, Think Pair Share (TPS), Numbered Heads Together (NHT), Group Investigation (GI), Two Stray Two Stay, Make a Match, Listening Team, Inside-Outside Circle, Bamboo Dancing, Point Counter Point, The Power of Two, Listening Two, PQ4R, Guided Note Taking, Snowball Drilling, Mind Mapping, Giving Question and Getting Answer, Question Student Have, Talking Stick, Everyone is Teacher Here, Tebak Pelajaran (Suprijono 2012).

Mind Mapping merupakan teknik visualisasi verbal kedalam gambar yang dapat membantu merekam, memperkuat, dan mengingat kembalin formasi yang telah dipelajari Makowitz (2002). Buzan (2000) berpendapat bahwa :

Mind mapping is an application that gives us the meaningful information to understand in a simple way. Mind Mapping Technique prepares the mind in a way that information can be used in logical and imaginary way to make an image in the brain. In Mind Mapping Technique first main idea is specified and then the linear view is explained. It is also useful for self and group in which it can have more effect than written review. This method is suitable for teachers and students for the recurrence and easy to understand hard topics (Parikh 2016: 149).

Buzan menjelaskan bahwa Mind mapping adalah aplikasi yang memberi kita informasi yang bermakna untuk dipahami dengan cara yang sederhana. Teknik Pemetaan Pikiran mempersiapkan pikiran sedemikian rupa sehingga informasi dapat digunakan secara logis dan 
imajiner untuk membuat gambar di otak. Dalam teknik Mind Mapping, ide utama ditentukan dan kemudian pandangan linear dijelaskan. Ini juga berguna untuk diri sendiri dan kelompok di mana ia dapat memiliki efek lebih dari ulasan tertulis. Metode ini cocok untuk guru dan siswa untuk pengulangan dan topik sulit yang mudah dipahami.

Dari dua pendapat ahli tersebut terlihat bahwa Mind Mapping merupakan model pembelajaran yang dirasa cocok untuk diterapkan pada pembelajaran yang memiliki muatan materi banyak seperti Ilmu Pengetahuan Sosial (IPS). Materi yang banyak akan sulit jika harus dihafalkan semuanya, kalaupun berhasil belajar dengan cara menghafal, ingatan mengenai materi tersebut tidak akan bertahan lama tinggal di otak. Ingatan mengenai materi yang diserap dengan cara menghafal akan terkikis seiring berjalannya waktu. Dengan penggunaan Mind Mapping akan membuat siswa lebih memahami materi pelajaran IPS, hal tersebut terbukti dari beberapa penelitian yang telah dilakukan. Penelitian tersebut diantaranya penelitian yang dilakukan oleh Natriani dan Ramlah (2015) dengan judul Penerapan Model Pembelajaran Mind Mapping dalam Meningkatkan Hasil Belajar pada Mata Pelajaran Ilmu Pengetahuan Sosial Siswa Kelas IV SDN 54 Kota Parepare. Hasil dari penelitian tersebut menunjukkan bahwa terjadi peningkatan hasil belajar IPS melalui penerapan model pembelajaran Mind Mapping pada siswa kelas IV SDN 54 Kota Parepare.

Hasil penelitian tersebut dikuatkan oleh Darmayoga dkk (2013). Penelitian dengan judul Pengaruh Implementasi Metode Mind Mapping Terhadap Hasil Belajar IPS Ditinjau Dari Minat Siswa Kelas IV SD SAI Denpasar dilaksanakan dengan metode eksperimen. Hasil dari penelitian tersebut yaitu hasil belajar IPS pada siswa yang mengikuti metode pembelajaran Mind Mapping lebih tinggi dibandingkan dengan hasil belajar siswa yang mengikuti metode pembelajaran konvensional. Perbedaan ini konsisten walaupun telah dilakukan pengendalian terhadap minat belajar siswa.

Dari berbagai hasil penelitian dapat disimpulkan bahwa Mind Mapping merupakan model pembelajaran berpengaruh positif terhadap hasil belajar siswa pada mata pelajaran IPS di Sekolah Dasar. Selain itu, model Mind Mapping dapat membantu siswa lebih aktif di kelas dan lebih mudah memahami materi dengan menggunakan kreatifitas masing-masing dalam pembuatan mind map. Model pembelajaran ini akan cocok jika diterapkan di SD N 3 Midang. Selama ini proses pembelajaran di SD Negeri 3 Midang terkesan monoton, ceramah masih menjadi metode favorit yang digunakan oleh guru dalam mengajar mata pelajaran IPS. Hal tersebut diketahui setelah melakukan wawancara dengan guru dan beberapa siswa di SD Negeri 3 Midang yang terletak di Kabupaten Lombok Barat. Penggunaan metode konvensional, dalam hal ini metode ceramah bukanklah sepenuhnya kesalahan guru. Sebagian besar guru yang telah senior memiliki informasi yang minim mengenai model pembelajaran baru yang menarik dan efektif untuk menghasilkan output yang baik. Selain itu, guru-guru yang masih muda malas untuk menerapkannya karena dirasa terlalu rumit dan membutuhkan waktu yang banyak untuk mempersiapkannya, sehingga pembelajaran yang inovatif sulit terlaksana di sekolah. Alasan-alasan yang dikemukakan guru mengenai keengganannya mengunakan model pembelajaran menunjukkan ketidakpahaman guru pada model pembelajaran yang ada. Model pembelajaran terkini pada hakekatnya memudahkan guru untuk melaksanakan proses pembelajaran yang efektif untuk mencapai tujuan pembelajaran yang diharapkan. 
Untuk membantu guru mengatasi permasalahan tersebut, dosen-dosen PGSD FKIP Universitas Mataram yang telah memiliki pemahaman konsepnya dapat berperan aktif, sehingga dapat mengurangi kendala dalam realisasinya. Melalui kegiatan pengabdian kepada masyarakat, dosen PGSD UNRAM melalukan worksop penyusunan rancangan pembelajaran menggunakan model mind mapping untuk SD Negeri 3 Midang.

\section{METODE KEGIATAN}

Kegiatan worksop penyusunan rancangan pembelajaran menggunakan model Mind Mapping dilaksanakan melalui dua tahap yaitu persiapan dan pelaksanaan. Tahap persiapan menggunakan metode koordinasi, observasi dan komunikasi, sedangkan paada tahap pelaksanaan menggunakan metode sosialisasi dan pelatihan. Pelaksanaan kegiatan workshop yang dilaksanakan sebagai berikut :

\section{Sosialisasi}

Sosialisasi dilakukan dengan cara menjelaskan mengenai segala hal berkaitan dengan model pembelajaran Mind Mapping. Dari menjelaskan pengertian, manfaat, hingga kelebihan dan kekuranan Mind Mapping. Langkah-langkah pembelajaran juga tak luput untuk disosialisasikan. Tujuan kegiatan ini adalah untuk memperkenalkan model pembelajaran Mind Mapping yang efektif dan dapat menjadi solusi dalam permasalahan pada mata pelajaran IPS. Selain memperkenalkan juga mengajak dan mempengaruhi guru-guru untuk mulai menggunakan model pembelajaran terkini yang efektif dan inovatif. Manfaatnya bukan hanya pada hasil belajar siswa, melainkan lebih dari itu dapat meningkatkan keaktifan siswa saat proses pembelajaran dan meningkatkan motivasi serta kreatifitas siswa dalam belajar.
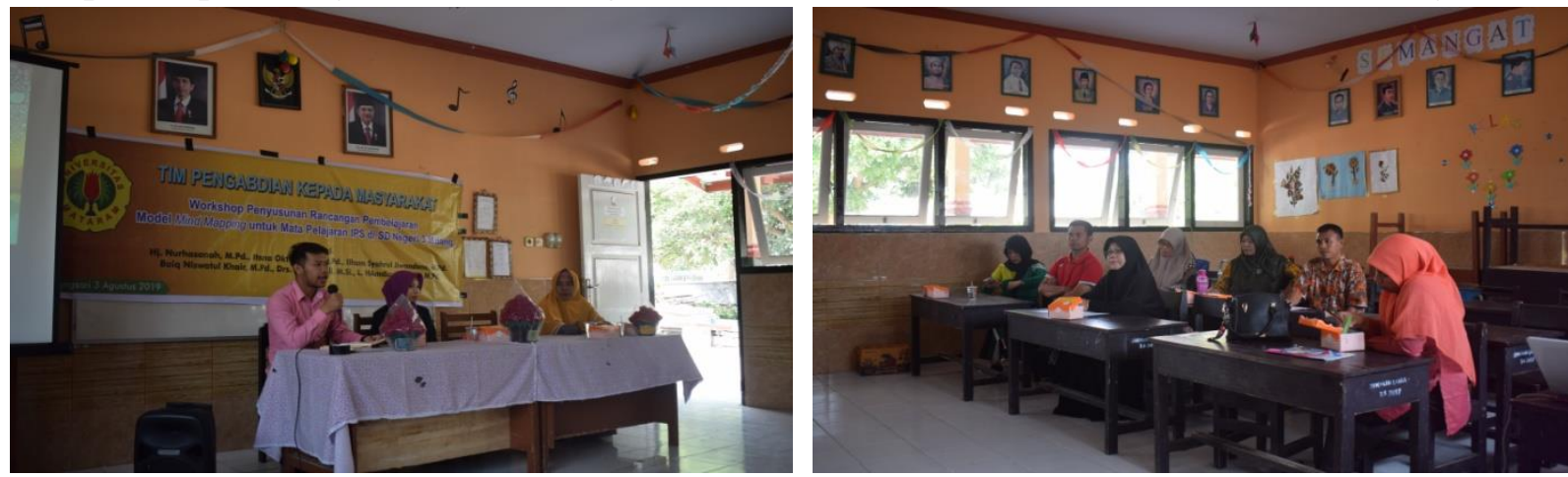

Gambar 1 dan 2. Sosialisasi mengenai konsep IPS dan Mind Mapping

\section{Pelatihan}

Setelah memahami konsep Mind Mapping melalui sosialisasi, selanjutnya tim pengabdian akan melakukan kegiatan inti yaitu pelatihan. Pelatihan dilakukan untuk mencapai dua target yaitu penyusunan rancangan pembelajaran dengan model Mind Mapping dan pelatihan pembuatan Mind Map untuk menunjang kegiatan pengajaran dengan model Mind Mapping.

Pelatihan penyusunan rancangan pembelajaran dengan model Mind Mapping. Pelatihan dilaksanakan dengan tujuan agar guru dapat menuangkan konsep Mind Mapping yang telah dipahami saat sosialisasi. Langkah awal kegiatan penyusunan rancangan 
pembelajaran sama dengan pembuatan RPP biasa. Penentuan KD dan indikator yang akan dibuat rancangan pembelajarannya, kemudian pada langkah-langkah pembelajaran digunakan model pembelajaran Mind Mapping. Tidak hanya terpaku dengan langkah-langkah pembelajarannya saja, melainkan hingga instrumen penilaian. Instrumen penilaian merupakan bagian dari rancangan pembelajaran. Dalam pembelajaran menggunakan model Mind Mapping, intrumen penilaian terbagi menjadi dua yaitu penilaian proses dan penilaian hasil. Penilaian proses terdiri dari dua yaitu proses pembelajaran yang menilai keaktifan siswa saat mengikuti pembelajaran dan penilaian proses pembuatan mind map. Penilaian hasil juga terbagi dua yaitu hasil belajar dengan menggunakan tes dan penilaian produk dari pembuatan mind map.

Setelah melakukan pelatihan penyusunan rancangan pembelajaran, selanjutnya diadakan pelatihan pembuatan Mind Map. Pelatihan ini dilakukan agar guru memahami dengan baik pembuatan mind map yang benar dan tidak asal-asalan. Hal tersebut dirasa penting karena siswa SD berada di masa perkembangan opersional konkrit, dimana mereka membutuhkan contoh yang nyata. Siswa SD tidak bisa langsung mengerjakan sesuatu hanya dengan menggunakan perintah verbal, namun harus diberi contoh dan arahan-arahan intensif dari guru. Guru yang mengusai teknik pembuatan mind map akan lebih mudah memberikan arahan atau bantuan kepada siswa.

\section{HASIL DAN PEMBAHASAN}

Kegiatan pengabdian kepada masyarakat ini dilakukan di SD Negeri 3 Midang, Kabupaten Lombok Barat. Kegiatan wokshop penyusunan rancangan pembelajaran model Mind Mapping untuk SD Negeri 3 Midang dilakukan dengan mensosialisasikan mengenai model pembelajaran Mind Mapping kemudian memberikan pelatihan pembuatan Mind Map, adapun rincian kegiatan pelaksanaan adalah sebagai berikut:

Kegiatan pengabdian diawali dengan pembukaan dan pengenalan masing-masing tim pengabdian PGSD UNRAM. Setelah selesai pengenalan, tim pengabdian memulai untuk menjelaskan mengenai materi sosialisasi yang telah disiapkan. Pemaparan pertama disampaikan oleh Ibu Hj. Nurhasanah mengenai Pengertian IPS dan masalah-masalah dalam mata pelajaran IPS pada umumnya serta masalah IPS di sekolah dasar pada khususnya. Masalah-masalah tersebut diantaranya muatan materi yang begitu banyak, sehingga butuh waktu ekstra dan strategi ampuh untuk menguasainya. Selain itu IPS seringkali dianggap sebagai mata pelajaran lapis kedua sehingga seringkali terabaikan, bahkan terkadang jam untuk mata pelajaran IPS dialihkan ketika mata pelajaran yang dianggap utama dirasa kekurangan waktu untuk mencapai tujuan pembelajaran. Kedua masalah tersebut berpengaruh terhadap metode pembelajaran yang digunakan, guru seringkali menggunakan metode pembelajaran yang monoton seperti ceramah dan mencatat. Ceramah bukan metode yang buruk, namun jika terus seperti itu, siswa akan merasa bosan dan tidak bersemangat mengikuti pembelajaran IPS.

Dengan berbagai masalah yang telah dipaparkan oleh Ibu $\mathrm{Hj}$ Nurhasanah, selanjutnya Ibu Itsna Oktaviyanti memparkan mengenai salah satu model pembelajaran yang dirasa 
cocok untuk digunakan pada proses pembelajaran IPS di SD. Pemaparan mengenai model Mind Mapping diantaranya penjelasan mengenai pengertian Mind Mapping, manfaat Mind Mapping, kelebihan Mind Mapping, kekurangan Mind Mapping dan langkah-langkah pembelajaran dengan model Mind Mapping. Peserta memperhatikan dengan seksama pemaparan mengenai pengertian Mind Mapping, karena dari pengakuan peserta belum familier dengan model tersebut. Mind Mapping sendiri merupakan model pembelajaran dengan mencatat hal-hal penting, memetakan pikiran-pikiran dengan cara yang menarik yaitu dalam bentuk gambar untuk membantu mengingat kembali informasi yang telah dipelajari. Setelah peserta terlihat paham dengan penjelasan, pemaparan selanjutnya mengenai manfaat Mind Mapping, model ini dirasa cocok untuk permasalahan yang terjadi pada mata pelajaran IPS khususnya, namun tidak menutup ruang bagi mata pelajaran lain. Hal tersebut dikarenakan model Mind Mapping dapat mempermudah siswa maupun guru dalam mengingat materi pembelajaran dengan cara yang menyenangkan. Manfaat yang terasa dari penggunaan model Mind Mapping tersebut merupakan representasi dari kelebihan Mind Mapping, namun setiap hal tidak hanya mempunyai kelebihan melainkan juga kekurangan. Kekurangan Mind Mapping juga dijelaskan agar guru dapat mengantisipasi hal tersebut. Kekurangan Mind Mapping tak terlepas dari waktu, membuat Mind Mapp yang menarik membutuhkan waktu yang lama, namun jika melihat hasilnya dan kebermanfaatannya maka kekurangan ini dapat ditoleransi.

Setelah penjelasan mengenai model Mind Mapping, Ibu Baiq Niswatur Khair menjelaskan mengenai perencanaan pembelajaran. Pemanfaatan Mind Mapping dalam proses pembelajaran perlu adanya perencanaan agar berjalan dengan lancar. Dalam membuat perencanaan pembelajaran, komponen-komponen yang diperlukan diantaranya kompetensi dasar, indikator pembelajaran, materi, langkah-langkah pembelajaran dengan model Mind Mapping dan penilaian. Ibu Baiq Niswatul Khair menjelaskan bahwa kompetensi dasar sudah ada dan baku sesuai dengan kurikulum yang sedang berlaku, sedangkan untuk indikator guru dapat mengembangkan sesuai dengan tujuan pembelajaran yang ingin dicapai. Kompetensi dasar dan indikator menjelaskan mengenai materi yang akan disampaikan oleh guru pada siswanya melalui proses pembelajaran. Penjelasan mengenai ketiga hal tersebut relatif cepat dan tidak banyak pertanyaan yang terlontar, hal tersebut dikarenakan peserta wokshop dalam hal ini guru sudah sangat akrab dengan ketiga komponen yang dibutuhkan dalam pembuatan perencanaan pembelajaran tersebut.

Berbeda dengan komponen yang dijelaskan oleh Ibu Baiq Niswatul Khair, komponen perencanaan pembelajaran yang dipaparkan oleh Bapak Ratnadi melahirkan banyak pertanyaan. Komponen yang dijelaskan yaitu langkah-langkah pembelajaran dengan model Mind Mapping. Langkah-langkah pembelajaran merupakan bagian dari perencanaan pembelajaran yang sebenarnya sudah cukup dipahami peserta, hanya saja dalam hal ini langkah pembelajaran dijelaskan berdasarkan model Mind Mapping sehingga masih cukup baru untuk para peserta. Hal tersebut terlihat jelas dari raut wajah para peserta yang begitu serius memperhatikan dan sesekali mengerutkan dahi sebagai tanda bahwa ada proses mencerna penjelasan dari Bapak Ratnadi selaku penyaji. Di sela sela penjelasan mengenai langkah pembelajaran Mind Mapping, peserta sesekali memberikan pertanyaan untuk memperjelas. Langkah-langkah model Mind Mapping yaitu penyampaian kompetensi yang 
ingin dicapai, penjelasan mengenai materi ajar, pembagian kelompok, kelompok ditugaskan membuat peta pikiran, presentasi dari masing-masing kelompok kemudian diakhiri dengan kesimpulan. Secara garis besar model pembelJrN Mind Mapping mencakup beberapa metode seperti ceramah, unjuk kerja, kerja kelompok dan presentasi.

Komponen terkahir pada perencanaan pembelajaran adalah penilaian. Bapak Lalu Hamdian Affandi selaku tim pengabdian menjelaskan mengenai penilaian pembelajaran. Bapak Hamdian, begitu beliau disapa menjelaskan terlebih dahulu jenis-jenis penilaian yang akan dilakukan jika menggunakan model Mind Mapping. Jenis penilain tersebut diantaranya performansi, penilaian produk dan hasil tes. Performansi dinilai saat siswa dalam kelompok mempresentasikan hasil kerja kelompoknya di depan kelas. Penilaian produk didapatkan dari hasil pembuatan Mind Map, penilaian ini didasarkan pada indikator-indikator penilaian yang relevan. Kemudian hasil tes dilakukan untuk mengetahui hasil belajar kognitif, hal ini dilakukan selain sebagai alat evaluasi kemampuan siswa menangkap materi juga sebagai alat penilaian keberhasilan penggunaan model Mind Mapping dalam pembelajaran. Peserta cukup paham dengan penjelasan mengenai penilaian yang digunakan dalam pembelajaran model Mind Mapping ini. Setelah itu, peserta pengabdian diminta untuk mencoba membuat perencanaan pembelajaran dengan menggunakan model Mind Mapping dengan kompetensi dasar, indikator dan materi yang telah disiapkan oleh tim pengabdian. Pembuatan perencanaan pembelajaran berjalan cukup lancar, sebagian besar peserta sudah memahaminya.

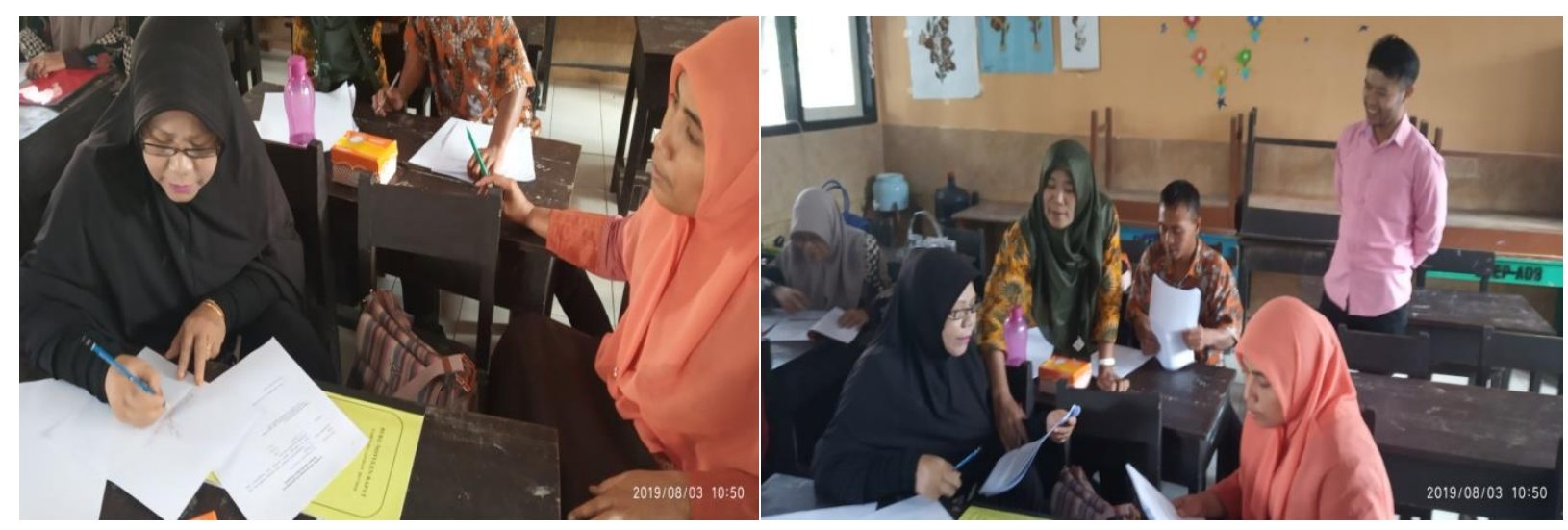

Gambar 3 dan 4. Penyususnan rancangan pembelajaran dengan model Mind Mapping

Setelah peserta selesai membuat perencanan pembelajaran, Bapak Ilham Syahrul Jiwandono mengajak peserta untuk membuat Mind Map atau peta pikiran dari materi yang telah diberikan yaitu Kerajaan Hindu Budha dan Islam di Indonesia. Sebelum proses pembuatan, Bapak Ilham terlebih dahulu menjelaskan langkah-langkah membuat Mind Map yaitu tema utama/ide utama di letakan di tengah kertas gambar sebagai pusat dari Mind Map, berikan cabang untuk anak dari ide utama dan untuk membuat lebih menarik gunakan symbol atau warna, setelah itu hubungan cabang-cabang dengan pusat, buatlah ranting-ranting yang berhubungan dengan cabang, masing-masing ranting ditulis dengan kata kunci yang berhubungan dengan ide utama, begitu seterusnya. Setelah penjelasan singkat mengenai langkah-langkah pembuatan Mind Map, tim pengabdian menjelaskan sesi selanjutnya setelah 
sosialisasi yaitu pelatihan pembuatan Mind Map, diawali dengan memberikan bahan-bahan pembuatan Mind Map seperti kertas gambar, pensil, spidol warna. Pembuatan Mind Map awalnya dilakukan secara berkelompok, namun saat berjalannya waktu, peserta merasa senang dan tertantang mengakibatkan beberapa peserta ingin membuat Mind Map sendiri. Antusiasme terlihat jelas pada raut wajah para peserta, hingga seorang peserta mengatakan bahwa guru saja senang membuat Mind Map apalagi siswa. Proses pembuatan Mind Map yang merupakan sesi akhir dari kegiatan pengabdian kepada masyarakat berjalan lancar dengan panduan dari tim. Kegiatan ditutup dengan doa dan kemudian melakukan foto bersama.
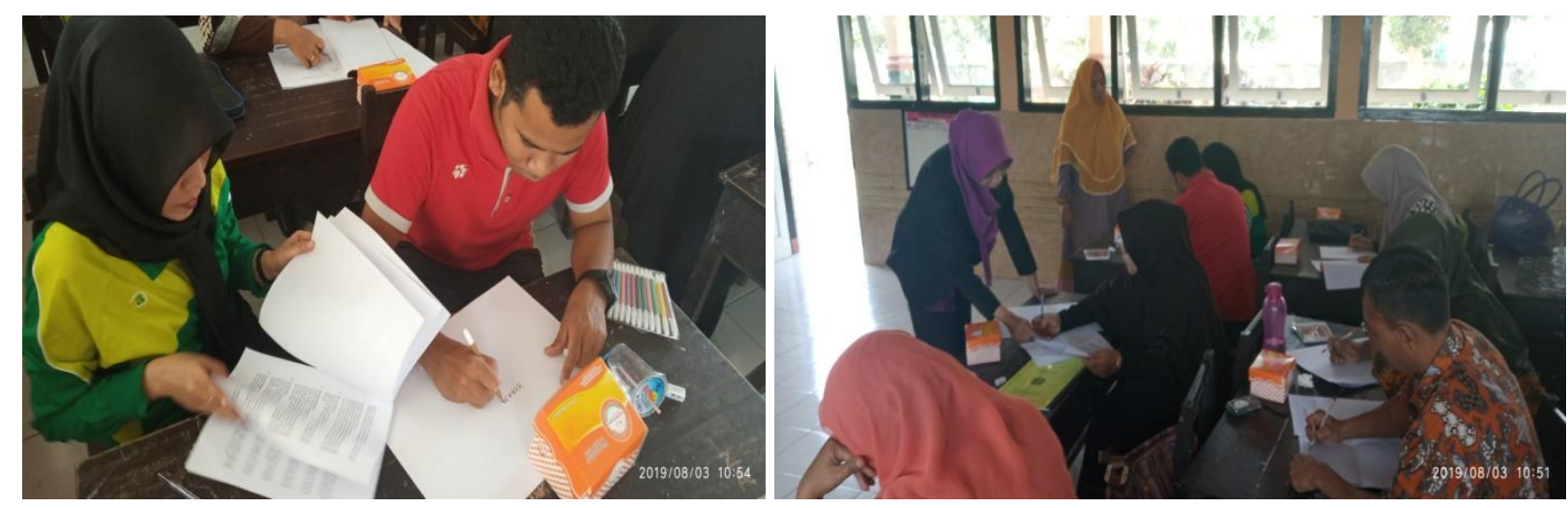

Gambar 5 dan 6. Pelatihan pembuatan Mind Map

\section{SIMPULAN DAN SARAN}

Berdasarkan hasil kegiatan pengabdian masyarakat yang bertajuk "Wokshop Penyusunan Rancangan Pembelajaran Model Mind Mapping untuk SD Negeri 3 Midang" yang telah dilaksanakan maka simpulan dari kegiatan ini adalah pelaksanaan kegiatan wokrshop berjalan lancar sesuai jadwal yang telah direncanakan dan cukup sukses. Tidak ada hambatan dan masalah selama kegiatan dan seluruh anggota tim pengabdian dapat hadir semua. Serangkaian kegiatan mulai tahap pembukaan, sosialisasi, pelatihan hingga penutupan berjalan lancar.

Terdapat beberapa hal yang dapat direkomendasikan dan dapat ditindaklanjuti dari hasil kegiatan ini adalah sebagai berikut:

1. Diperlukan kesadaran akan pentingnya penggunaan model pembelajaran inovatif yang dapat membantu guru dalam proses pembelajaran bukan malah sebaliknya.

2. Diperlukan pendampingan yang intensif dan kerjasama semua pihak seperti kepala sekolah dan guru sendiri agar pemahaman mengenai model Mind Mapping yang telah didapatkan diimplementasikan dalam proses pembelajaran.

3. Diperlukan peningkatan kualitas pemahaman guru mengenai model pembelajaran lain selain Mind Mapping agar proses pembelajaran lebih variatif dan menyenangkan. 
4. Diperlukan pembiasaan pada guru untuk terus merancang pembelajaran dengan menggunakan model pembelajaran yang inovatif, tidak hanya sesaat setelah kegiatan wokshop

5. Adanya kerjasama yang berkelanjutan antara SD Negeri 3 Midang dengan Prodi PGSD Universitas Mataram dalam memperkenalkan model pembelajaran lain yang inovatif dan sesuai dengan tuntutan jaman.

\section{Ucapan Terimakasih}

Tim pengabdian kepada masyarakat mengucapkan terimakasih kepada Rektor Universitas Mataram, Ketua LPPM Universitas Mataram, Dekan Fakultas Keguruan dan Ilmu Pendidikan Universitas Mataram, Kepala SDN 3 Midang Lombok Barat dan seluruh jajarannya, serta semua pihak yang telah berkontribusi terhadap kegiatan ini.

\section{DAFTAR PUSTAKA}

Abdul Majid, Perencanaan Pembelajaran (Bandung : Remaja Rosdakarya, 2012)

Darmayoga, I Wayan., I Wayan Lesama dan Marhaeni. 2013. Pengaruh Implementasi Metode Mind Mapping Terhadap Hasil Belajar IPS Ditinjau Dari Minat Siswa Kelas IV SD Sathya SAI Denpasar. Universitas Pendidikan Ganesha: Vo;. 3

Isjoni. 2010. Cooperative Learning Efektivitas Pembelajaran Kelompok. Bandung: Alfabeta Kementrian Pendidikan dan Kebudayaan. 2016. Standar Proses Pendidikan Dasar dan Menengah. Jakarta: Peraturan Menteri Pendidikan dan Kebudayaan No.22 Tahun 2016

Latipah, Hani Wardah., dan Adman. 2018. Penerapan Model Pembelajaran Mind Mapping untuk Meningkatkan Hasil Belajar Peserta Didik (Studi Kuasi Eksperimen Pada Kompetensi Dasar Mengidentifikasikan Fasilitas dan Lingkungan Kantor Kelas X Program Keahlian Administrasi Perkantoran di SMKN 3 Bandung). UPI: Vol.1_No.2_hal. 125-137

Makowitz, Jensen., Eric dan Karen. 2002. Otak Sejuta Gygabite: Buku Pintar Membangun Ingatan Super. Bandung: Kaifa

Mustofa Ali. dkk., 2011. Bahan Ajar Perencanaan Pembelajaran

Natriani, Syam dan Ramlah. 2015. Penerapan Model Pembelajaran Mind Mapping Dalam Meningkatkan Hasil Belajar pada Mata Pelajaran Ilmu Pengetahuan Sosial Siswa Kelas IV SDN 54 Kota Pare Pare. UNM: ISSN 2088-2092. Vol 5. No. 3

Parikh, Nikhilkumar D. 2016. Effectiveness of Teaching through Mind Mapping Technique. The International Journal of Indian Psychol. ISSN: 2349-3429 (p) Volume 3, Issue 3, No.3

Rusman. 2011. Model-model Pembelajaran Mengembangkan Profesionalisme Guru. Jakarta: Raja Grafindo Persada

Suprijono, Agus. 2012. Cooperative Learning Teori dan Aplikasi PAIKEM. Yogyakarta: Pustaka Pelajar

Trianto. 2011. Model Pembelajaran Terpadu: Konsep, Strategi, dan Implementasinya dalam Kurikulum Tingkat Satuan Pendidikan (KTSP). Jakarta: Bumi Aksara 